\title{
MEMURNIKAN KEWENANGAN MAHKAMAH KONSTITUSI SEBAGAI LEMBAGA PENGAWAL KONSTITUSI (THE GUARDIAN OF THE CONSTITUTION)
}

\author{
Sudirman \\ Jurusan Hukum Kewarganegaraan Universitas Negeri Malang \\ Jl. Semarang No. 5 Malang \\ email: sudirfar@gmail.com
}

\begin{abstract}
Stated in constitution (UUD NRI Tahun 1945), one of Constitutional Court authority is guarding the constitution, that means reviewing any law against the constitution. Whereas review any ordinances and regulation made under law would fall into the authority of Supreme Court. Based on stufen theory, ordinances and regulation made under law is inseparable and is the continuation of the constitution, so that authority review must fall under Constitutional Court as the guardian of the constitution. But constitution regulations see ordinances and regulation made under any law should be separated from constitution, so review authority fall under Supreme Court. This condition provokes dualism judicial review, addressing problems that able to disturb the goverment system of Indonesia. This article elaborates dualism judicial review problem and idea of purifying constitutional court authority as the guardian of constitution.
\end{abstract}

Keyword: authority, constitutional court, judicial rewiew.

\begin{abstract}
Abstrak: Dalam Undang-Undang Dasar NRI Tahun 1945, salah satu kewenangan Mahkamah Konstitusi adalah mengawal konstitusi yaitu menguji undang-undang terhadap Undang-Undang Dasar. Sedangkan uji peraturan di bawah undang-undang terhadap undang-undang dilakukan oleh Mahkamah Agung. Apabila disandarkan pada teori jenjang, peraturan perundang-undangan di bawah undang-undang dipandang sebagai derivasi konstitusi yang tidak bisa dipisahkan dari konstitusi tersebut, maka hak ujinya harus diserahkan kepada Mahkamah Konstitusi sebagai lembaga pengawal konstitusi. Ketentuan konstitusi justru memandang peraturan perundang-undangan di bawah undang-undang terlepas dari keterkaitannya dengan konstitusi, sehingga hak ujinya diserahkan kepada Mahkamah Agung. Oleh karena itu terdapat dualisme judicial review yang pada akhirnya menghadirkan problematika yang dapat menggangu proses berjalannya sistem ketatanegaraan di Indonesia. Tulisan ini menjabarkan problematika dualisme judicial review dan gagasan memurnikan kewenangan Mahkamah Konstitusi sebagai pengawal konstitusi.
\end{abstract}

Kata Kunci: kewenangan, mahkamah konstitusi, judicial review

Berdasarkan Pasal 1 Ayat (1) Undang-Undang Dasar 1945 "Negara Indonesia ialah Negara kesatuan yang berbentuk Republik". Berdasarkan pada ketentuan pasal tersebut menunjukkan negara Indonesia merupakan negara kesatuan atau unitary state (eenheidsstaat). Dalam negara kesatuan tidak dikenal negara bagian, sehingga tidak ada negara dalam negara. Sistem pemerintahan terdiri dari pemerintahan pusat dan beberapa pemerintahan daerah yang terikat dalam satu kesatuan sistem pemerintahan. Berdasarkan logika negara kesatuan, menurut Jimly adalah logis mengembangkan pengertian bahwa pemerintah atasan berwenang melakukan kontrol terhadap unit pemerintahan bawahan. Artinya pemerintah pusat dalam konteks Negara Kesatuan Republik Indonesia berdasarkan UUD 1945 tentu dapat mempunyai kewenangan untuk mengontrol unit-unit pemerintahan daerah provinsi ataupun pemerintahan daerah kabupaten dan kota. Demikian juga pemerintahan provinsi juga dapat diberi kewenangan tertentu dalam rangka mengendalikan jalannya pemerintahan daerah kabupaten dan kota di bidang pengaturan (Asshiddiqie, 2006: 107). 
Mekanisme kontrol yang dilakukan pemerintah atasan itu antara lain adalah kontrol atas norma hukum yang ditetapkan oleh pemerintah bawahan melalui apa yang dikenal sebagai "general norm control mechanism". Mekanisme kontrol norma umum inilah yang biasa disebut dengan sistem "abstract review" atau pengujian abtrak yang dapat dilakukan oleh lembaga eksekutif, lembaga legislatif, ataupun lembaga pengadilan. Jika "abstract review" itu dilakukan oleh lembaga eksekutif, misalnya pengujian oleh pemerintah pusat atas peraturan pemerintah daerah provinsi, maka mekanisme demikian disebut "executive review". Jika "abstract review" dilakukan oleh DPRD dan pemerintah daerah yang menetapkan peraturan daerah itu sendiri, maka peninjauan kembali seperti itu disebut "legislative review" yang dapat menghasilkan perubahan (amandement) peraturan. Jika pengujian itu dilakukan oleh pengadilan, maka hal itulah yang biasa disebut sebagai "judicial review" (Asshiddiqie, 2006:107).

Kewenangan untuk melakukan "executive preview" itulah yang sebaiknya diberikan kepada pemerintahan atasan, bukan mekanisme "review" atas peraturan daerah yang sudah berlaku mengikat untuk umum. Jika suatu peraturan yang dibentuk oleh lembaga eksekutif dan legislatif yang sama-sama dipilih langsung oleh rakyat melalui pemilihan umum dibatalkan hnya oleh pejabat eksekutif tingkat atas, berarti "prinsip negara kesatuan" dijadikan dalih untuk mengebiri aspirasi rakyat dengan tindakan yang semata-mata didasarkan atas pertimbangan politik (Asshiddiqie, 2006:109).

Berdasarkan ulasan tersebut, memberikan landasan konsep bahwa yang paling ideal menerima kewenangan review adalah pengadilan. Sehingga tidak mengherankan apabila kewenangan judicial review dalam UndangUndang Dasar 1945 dilimpahkan kepada kekuasaan kehakiman yaitu Mahkamah Konstutusi dan Mahkamah Agung. Kewenangan Mahkamah Konstitusi dalam melakukan judicial review secara eksplisit tertuang dalam Pasal 24C Ayat (1) yang berbunyi "Mahkamah Konstitusi berwenang mengadili pada tingkat pertama dan terakhir yang putusannya bersifat final untuk menguji undang-undang terhadap undang-undang dasar, memutus sangketa kewenangan lembaga Negara yang kewenangannya diberikan oleh Undang Undang Dasar, memutus pembubaran partai politik dan memutus perselisihan tentang hasil pemilihan umum". Sedangkan kewenangan Mahkamah Agung tertuang dalam Pasal 24AAyat (1) yang berbunyi "Mahkamah Agung berwenang mengadili pada tingkat kasasi, menguji peraturan perundang-undangan di bawah undang-undang terhadap undang-undang, dan memiliki kewenangan lainnya yang diberikan oleh undangundang".

Ketentuan tersebut cukup menarik dalam diskursus ketatanegaraan Indonesia yaitu Mahkamah Konstitusi hanya berwenang menguji undang-undang terhadap Undang-Undang Dasar. Keberadaan Mahkamah Konstitusi dalam gagasan awalnya adalah sebagai lembaga pengawal konstitusi. Apabila disandarkan pada teori jenjang yang dikemukakan Hans Kelsen dan Hans Nawiasky, peraturan perundang-undangan di bawah undang-undang dipandang sebagai derivasi konstitusi yang tidak bisa dilpisahkan dari konstitusi tersebut, makan hak ujinya harus diserahkan kepada Mahkamah Konstitusi sebagai lembaga pengawal konstitusi. Ketentuan yang ada justru memandang peraturan perundang-undangan di bawah undang-undang terlepas dari keterkaitannya dengan konstitusi, sehingga hak ujinya diserahkan kepada Mahkamah Agung. Namun. Tidak mengherankan apabila dualisme judicial review akan menghadirkan problematikan yang dapat menggangu proses berjalannya sistem ketatanegaraan di Indonesia

\section{KEWENANGAN HAK UJI PERATURAN PERUNDANG-UNDANGAN DI INDONE- SIA}

Hak uji peraturan perundang-undangan di Indonesia dilakukan oleh dua lembaga yaitu Mahkama Konstitusi dan Mahkamah Agung. Mahkamah Konstitusi merupakan salah satu lembaga negara yang melaksanakan kekuasaan kehakiman, ketentuan ini berdasarkan Pasal 24 Ayat (2) UUD 1945 yang berbunyi: kekuasaan kehakiman dilakukan oleh sebuah Mahkamah Agung dan badan peradilan yang berada di bawahnya dalam lingkungan peradilan umum, lingkungan peradilan agama, lingkungan peradilan agama, lingkungan peradilan militer, lingkungan perdilan tata usaha negara, dan oleh sebuah Mahkamah Konstitusi. Kemudian dipertegas oleh Pasal 2 Undang-Undang No. 4 Tahun 2004 yang berbunyi: Mahkamah Konstitusi merupakan salah 
satu lembaga negara yang melakukan kekuasaan yang merdeka untuk menyelenggarakan peradilan guna menegakkan hukum dan keadilan. Ketentuan tersebut mengandung beberapa hal pokok yang melekat pada Mahkamah Konstitusi yaitu: (a) Mahkamah Konstitusi salah satu lembaga negara, (b) Fungsinya melakukan kekuasaan kehakiman untuk menyelenggarakan peradilan guna menegakkan hukum dan keadilan, (c) dalam melaksanakan penyelenggaraan peradilan bersifat merdeka (Harahap, 2008:15).

Kewenangan Mahkamah Konstitusi dalam menguji peraturan perundang-undangan tertuang dalam Undang-undang Dasar Republik Indonesia, Pasal 24C Ayat (1) "Mahkamah Konstitusi berwenang mengadili pada tingkat pertama dan terakhir yang putusannya bersifat final untuk menguji undang-undang terhadap undang-undang dasar, memutus sangketa kewenangan lembaga Negara yang kewenangannya diberikan oleh Undang Undang Dasar, memutus pembubaran partai politik dan memutus perselisihan tentang hasil pemilihan umum". Kemudian ditegaskan kembali dalam Pasal 10 Ayat (1) Undang-Undang No. 4 Tahun 2004 yang berbunyi: Mahkamah Konstitusi berwenangan mengadili pada tingkat pertama dan terakhir yang putusannya bersifat final untuk (a) menguji undang-undang terhadap Undang-Undang Dasar Republik Indonesia Tahun 1945; (b) memutus sangketa kewenangan lembaga negara yang kewenangannya diberikan oleh Undang-Undang Dasar Republik Indonesia Tahun 1945; (c) memutus pembubaran partai politik; dan (d) memutus perselisihan tentang hasil pemilihan umum (Harahap, 2006: 15-16). Ketentuan tersebut melahirkan konsekwensi: (a) penyelenggara peradilan yang berdiri sendiri, dibawahnya tidak diletakkan badan perdilan lain, (b) kewenangan peradilan yang diberikan bersifat tingkat pertama dan terakhir (first and last instance), (c) putusan yang dijatuhkan Mahkamah Konstitusi langsung bersifat final (final judgment), sehingga ditutup segala upaya hukum apapun.

Di samping Mahkamah Konstitusi, Mahkamah Agung juga memiliki kewenangan uji peraturan perundang-undangan. Kewenangan Mahkamah Agung adalah uji peraturan di bawah undang-undang terhadap undang-undang sebagaimana tertuang dalam Pasal 24A Ayat (1) yang berbunyi "Mahkamah Agung berwenang mengadili pada tingkat kasasi, menguji peraturan perundang-undangan di bawah undang-undang terhadap undang-undang, dan memiliki kewenangan lainnya yang diberikan oleh undangundang".

Oleh karena itu dalam praktik ketatanegaraan terjadi dualisme judicial review, yaitu Mahkamah Konstitusi hanya berwenang melakukan judicial review undang-undang terhadap Undang Undang Dasar, selebihnya uji peraturan dibawah undangundang dilakukan oleh Mahkamah Agung. Kondisi demikian menimbulkan problematika kewenangan uji peraturan perundang-undangan (yudicial review) di Indonesia.

\section{PROBLEMATIKA DUALISME HAK UJI PERATURAN PERUNDANG-UNDANGAN}

\section{Pengingkaran Stufen Theory dan Undang- Undang Dalam Arti Materiel (wet in materiele zin)}

Hans Kelsen memaparkan bahwa tata hukum bukan merupakan sistem norma yang dikoordinasikan satu dengan lainnya, tetapi berupa suatu hirarki dari norma-norma yang memiliki level berbeda. Kesatuan norma ini disusun oleh fakta bahwa pembuatan norma, yang lebih rendah, ditentukan oleh norma lain, yang lebih tinggi. Pembuatan yang ditentukan oleh norma lebih tinggi menjadi alasan utama validitas keseluruhan tata hukum yang membentuk kasatuan (Asshiddiqie dan Safa'at, 2006:110). Berdasarkan ketentuan tersebut, suatu sistem hukum membentuk suatu pola tertinggi sampai terendah. Norma hukum tertinggi menjadi dasar norma dibawahnya, demikian seterusnya sampai norma yang paling bawah. Pola demikian disebut dengan piramuda hukum (stufen theory), yaitu: (a) basic norm (norma dasar), (b) enabling art (secondary norm expresing primary norm), (c) byelaw (secondary norm expresing primary norm), (d) specific official Action (particularly primary norm) (Ali, 2009:63).

Teori yang dikemukakan oleh Hans Kelsen tersebut kemudian dikembangkan oleh Hans Nawiasky dengan theorie von stufenufbau der re-chtsordnung. Susunan piramida norma menurut teori ini adalah: (1) norma fundamental negara (Staatfundamentalnorm), (b) aturan dasar negara (staatsgrundgesetz), (c) Undang-undang formal (Formell gesetz), (d) peraturan pelaksana dan peraturan otonom (verordnung en autonome satzung) (Asshiddiqie dan Safa'at, 2006:170). 
Kedua teori tersebut memiliki perbedaan dimana menurut Hans Kelsen norma tertinggi merupakan Grundnorm, sedangkan Hans Nawiasky memiliki pandangan berbeda dengan menempatkan posisi tertinggi Staatfundamentalnorm. Namun menjadi benang merah dari kedua teori tersebut adalah norma di bawahnya tidak boleh bertentangan dengan norma yang di atasnya sebagian ataupun seluruhnya dan secara materiil maupun formil, karena peraturan di bawah merupakan derivasi dari norma yang di atasnya. Dalam konteks Indonesia, semua peraturan perundang-undangan merupakan derivasi dari Undang-Undang Dasar, sehingga segala uji peraturan di bawah UUD memiliki derivasi linier terhadap uji terhadap UUD. Oleh karena itu berdasarkan teori Hans Kelsen dan Hans Nawiasky uji segala peraturan perundangundangan di bawah undang-undang dilakukan oleh lembaga yang mengawal konstitusi yaitu Mahkamah Konstitusi.

Kemudian dianalisis dari konsep wet dalam bahasa belanda. Wet/undang-undang dapat dilihat dari pengertian secara materiil dan secara formil. Menurut A. Hamid. S Attamimi (Al Atok. 2012:60), undang-undang dalam arti materiil (wet in materiele zin) dimaksudkan adalah segala bentuk peraturan perundang-undangan, sedangkan undang-undang dalam arti formil (wet in formale zin) lazim disebut dengan Undang-Undang saja. Apabila ditinjau secara formal jelas bahwa undang-undang merupakan produk perturan perundang-undangan yang merupakan produk legslatif (DPR) bersama dengan Presiden. Lain halnya apabila dilihat secara materiil, undangundang tidak hanya terbatas peraturan yang dibuat oleh lembaga legislatif (DPR) bersama DPR, melainkan juga seluruh peraturan perundangundangan, tentunya yang dibuat oleh lembaga yang berwenang, yang secara substansi memiliki maksud mengatur kehidupan masyarakat dan mengikat secara umum. Sehingga apabila mengacu pada definisi secara materiil, seluruh peraturan perundang-undangan mulai dari peraturan daerah sampai dengan undang-undang dapat dikatan sebagai undang-undang.

Hal tersebut selaras dengan analisis yang dikemukakan oleh Jimly, yang mengatakan apabila kewenangan untuk menguji peraturan daerah diberikan kepada Mahkamah Agung, berarti peraturan daerah mutlak hanya sebagai salah satu bentuk peraturan perundang-undangan yang berada di bawah undang-undang. Namun, berdasarkan ketentuan Pasal 24C Ayat (1) UUD 1945, hanya menyebut "undang-undang" dengan huruf kecil. Artinya, kualifikasi "undang-undang" dimaksud belum rinci. Jika ditafsirkan bahwa dalam kata "undang-undang" tersebut dapat tercakup juga pengertian "undang-undang dalam arti materiel" (wet in materiele zin), maka niscaya substansi peraturan daerah dapat dilihat sebagai "wet in materiele zin" yang berbaju peraturan daerah. Sejalan dengan hal itu, dapat dikatakan bahwa dari segi bentuknya peraturan daerah itu betapapun juga memang merupakan peraturan lokal, tetapi sebenarnya, dari segi isinya ia juga adalah undang-undang dalam arti materiel (wet in materiele zin), yaitu sebagai undang-undang lokal (locale wet). Oleh karena itu, Mahkamah Konstitusi juga napat menafsirkan bahwa peraturan daerah itu sebagai "locale wet in materiele zin" juga dapat dijadikan sebagai objek pengujian konstitusional yang harus dijalankan sebagai lembaga pengawal kostitusi (Asshiddiqie, 2006:111).

Selain itu pembagian kewenangan uji peraturan perundang-undangan antata Mahkamah Konstitusi dengan Mahkamah Agung dapat menimbulkan perbedaan atau putusan yang saling bertentangan antara Mahkamah Konstitusi dengan Mahkamah Agung. Misalnya ketika MK melakukan pengujian terhadap sebuah UU "A" terhadap UUD dan disaat yang sama MA juga melakukan pengujian terhadap sebuah peraturan perundang-undangan dibawa undang-undang " $B$ " yang merupakan derivasi dari UU "A". Secara bersamaan dalam pengujian tersebut MK memutuskan bahwa UU "A" tersebut bertentangan dengan UUD namun dalam putusan MA ternyata diputuskan bahwa produk hukum "B" berkesesuaian dengan UU "A" (Asshiddiqie, 2004:188).

\section{Pengingkaran Ketentuan Sentralisasi Kekuasaan Kehakiman}

Judicial review sebagai sebuah bentuk kewenangan untuk menguji peraturan perundangundangan terhadap peraturan yang lebih tinggi berkembang dalam sistem hukum yang berbeda yaitu sistem hukum eropa (civil law) dan sistem common law. Dalam negara yang menganut sistem hukum civil law Judicial review diserahkan kepada satu lembaga tertinggi saja yang dikenal 
dengan "Constitucional Court" atau Mahkamah Konstitusi. Cara pengujian oleh satu mahkamah tersebut dikenal dengan "sentralisasi" sedangkan sistem pengujiannya disebut "principaliter" (Lotulung, dalam A Thalib, 2006: 227). Sedangkan negara yang menganut sistem "common law", Judicial review diberikan kepada para hakim yang bertugas untuk menguji apakah peraturan yang dipermasalahkan dalam kasus yang sedang diperiksa bertentangan dengan konstitusi. Sistem pengujian oleh para hakim tersebut diistilahkan "desentraisasi" dan metode pengujiannya disebut "incidenter" (Lotulung dalam AThalib, 2006:228).

Masih Dalam diskursus mengenai teori sentralisasi dan desentralisasi judicial review tersebut, Vicki C. Jackson dan Mark Tushnet membagi dua bentuk atau model lembaga yang melaksanakan constitutional judicial review (pengujian konstitusionalitas oleh lembaga peradilan), yaitu pertama, the decentralized model dan kedua adalah the centralized model. The decentralized model atau disebut juga model Amerika atau dalam istilah yang lebih rumit disebut "diffuse model involving incidental review", menurut Jackson dan Tushnet pada model ini kekuasaan untuk melakukan judicial review tidak dijalankan oleh satu lembaga peradilan saja. $R e$ view dapat dilakukan oleh banyak lembaga peradilan seperti peradilan federal maupun peradilan negara bagian di Amerika. Model kedua adalah the centralized model yang biasa disebut juga dengan model Austria atau model Eropa. Ciri utama model ini adalah terdapatnya lembaga khusus dalam melakukan kewenangan judicial review._Khusus disini bermakna tidak terdapat lembaga lain atau lembaga peradilan lain yang melakukan kewenangan judicial review (Amsari, 2008).

Sistem hukum Indonesia lebih bercorak civil law dibandingkan dengan common law, meskipun pasca reformasi dan amandemen UUD 1945 terjadi pengadopsian beberapa aspek sistem hukum rule of law. Sebagai negara yang menganut sistem hukum civil law, membawa konsekwensi sistem ketatanegaraan Indonesia kental dengan corak sistem hukum civil law, diataranya kekuasaan kehakiman. Dalam sistem hukum civil law kekuasaan kehakiman bersifat sentralistik yang berpusat pada Mahkamah Agung dan Mahkamah Konstitusi. Ketentuan mengenai hal ini tertuang dalam Pasal 24A Ayat (1) dan Pasal 24C Ayat (1) UUD 1945 yang memberikan landasan yuridis bahwa negara Indonesia menganut sistem kekuasaan kehakiman sentralitik. Corak kekuasaan kehakiman dalam sistem civil law memiliki perbedaan signifikan dibandingkan corak kekuasaan kehakiman dalam sistem hukum common law yang bersifat desentalistik. Dalam model desentralistik kekuasaan kehakiman tidak dijalankan oleh satu lembaga peradilan saja, tetapi dapat dilakukan oleh banyak lembaga peradilan seperti peradilan federal maupun peradilan negara bagian.

Demikian halnya dengan kewenangan judicial review peraturan perundang-undangan terhadap peraturan yang lebih tinggi berkembang dalam sistem hukum yang berbeda antara sistem civil law dan sistem common law. Dalam negara yang menganut sistem hukum civil law, judicial review diserahkan kepada satu lembaga tertinggi saja yang dikenal dengan Mahkamah Konstitusi. Sedangkan negara yang menganut sistem "common law", judicial review diberikan kepada para hakim baik dalam mahkamah agung ataupun hakim dilingkungan peradilan negara bagian.

Terjadinya dualisme judicial review di Indonesia dengan memisahkan hak uji peraturan perundang-undangan antara Mahkamah Konstitusi yang hanya memiliki kewenangan melakukan uji undang-undang Terhadap Undang-Undang Dasar 1945 dan Mahkamah Agung yang memiliki kewenangan uji peraturan perundang-undangan di bawah undang-undang terhadap undang-undang, telah menghadirkan kekaburan konsep kekuasaan kehakiman yang dianut Indonesia. Sebagai negara yang kental dengan corak civil law seharusnya kewenangan hak uji peraturan perundangundangan murni menjadi milik Mahkamah Konstitusi, sedangkan kewenangan mengawal keadilan masyarakat diintegrasikan dalam kewenangan Mahkamah Agung.

\section{Kelemahan Hak Uji Peraturan Perundang- undangan di Tangan Mahkamah Agung}

Kewenangan Mahkamah Agung dalam melakukan uji peraturan perundang-undangan sudah ada sebelum amandemen ke-3 UUD 1945, artinya kewenangan itu ada sebelum Mahkamah Konstitusi dibentuk. Ketentuan demikian ditegaskan dalam ketentuan MPR No. III/MPR/ 2000. Sehingga ketentuan tersebut dipertahankan dalam perubahan ke-3 UUD 1945. Kondisi tersebut didasari adanya negara lain yang dijadikan salah satu sumber inspirasi oleh para anggota ad 
hoc I Badan Pekerja MPR ketika merumuskan ketentuan mengenai Mahkamah Konstitusi Ini, yaitu Korea Selatan. Dalam konstitusi Korea Selatan, kewenangan judicial review (contitutional review) atas undang-undang memang diberikan kepada Mahkamah Konstitusi, tetapi kewenangan judicial review atas peraturan di bawah undang-undang diberikan kepada Mahkamah Agung (Asshiddiqie, 2004: 189).

Namun ketentuan tersebut justru melahirkan kelemahan. Kelemahan tersebut tercermin dalam penerapan hak tersebut seperti tertuang dalam Pasal 31 Ayat (3) Undang-Undang No. 14 Tahun 1985 sebagaimana diubah dengan UU No. 5 Tahun 2004 tentang Mahkamah Agung yang berbunyi "putusan mengenai tidak sahnya peraturan perundang-undangan dapat diambil baik berhubungan dengan pemeriksaan pada tingkat kasasi maupun berdasarkan permohonan langsung pada Mahkamah Agung".

Konsekwensi ketentuan ini tidak baik bagi pelaksanaan uji peraturan perundang-undangan. Dianalisis secara mendalam terdapat kelemahan yang dapat menghambat proses uji peraturan perundang-undangan, apabila melalui mekanisme kasasi terdapat beberapa problematika diantaranya:

1) Penyelesaian sangketa dalam uji peraturan perundang-undangan baik secara formil maupun secara materiil apabila dilakukan melalui mekanisme kasasi akan memakan waktu yang cukup panjang. Mengingat mekanisme kasasi dapat dilakukan dengan terlebih dahulu melalui peradilan tingkat pertama dan peradilan tingkat banding.

2) Mekanisme uji peraturan perundang-undangan dengan metode kasasi tidak memberikan kepastian hukum. Hal ini dapat terjadi apabila perkara sangketa hak uji perturan perundangundangan berhenti di peradilan tingkat pertama, atau peradilan tingkat banding tanpa adanya upaya mengajukan dalam tingkat kasasi, maka Mahkamah Agung tidak memiliki kewenangan untuk melakukan uji peraturan perundangundangan meskipun peraturan perundangundangan tersebut jelas-jelas bertentangan dengan peraturan yang di atasnya. Sehingga peraturan itu akan terus eksis dan berlaku.

Sedangkan apabila menggunakan mekanisme permohonan langsung ke Mahkamah Agung justru akan menimbulkan delema lain yang tidak kalah peliknya. Berdasarkan ketentuan Pasal
24 Ayat (2) UUD 1945 yang berbunyi: kekuasaan kehakiman dilakukan oleh sebuah Mahkamah Agung dan badan peradilan yang berada di bawahnya dalam lingkungan peradilan umum, lingkungan peradilan agama, lingkungan peradilan agama, lingkungan peradilan militer, lingkungan perdilan tata usaha negara, dan oleh sebuah Mahkamah Konstitusi. Berdasarkan ketentuan tersebut nampak jelas bahwa Mahkamah Agung bukan merupakan Lemabaga mandiri yang berdiri sendiri, di bawahnya terdapat berbagai lingkungan peradilan yang kesemuanya berpuncak pada Mahkamah Agung. Dalam arti yang sederhana kekuasaan Mahkamah Agung mengikuti sistem sentralistik, sehingga proses peradilan yang dijalankan mengikuti pola yang serupa yaitu peradilan tingkat pertama, peradilan tingkat banding, dan peradilan tingkat kasasi. Tingkat kasasi inilah yang menjadi kewenangan Mahkamah Agung.

Jadi berdasarkan uraian tersebut, dapat diperoleh kejelasan bahwa kewenangan Mahkamah Agung yang dilimpahkan dari konstitusi adalah kewenangan yang bersifat terakhir tetapi tidak bersifat yang pertama. Berbeda dengan kewenangan Mahkamah Konstitusi yang secara eksplisit bersifat pertama dan terakhir. Sehingga ketentuan permohonan uji peraturan perundangundangan yang langsung diajukan ke Mahkamah Agung tanpa melalui mekanisme kasasi akan merubah sifat kewenangan Mahkamah Agung menjadi yang pertama dan terakhir. Oleh karenanya, ketetentuan Pasal 31 Ayat (3) Undang-Undang No. 14 Tahun 1985 sebagaimana diubah dengan UU No. 5 Tahun 2004 tersebut di atas, secara meteriil mengingkari ketentuan yang di atasnya yaitu Pasal 24 Ayat (2) UUD 1945.

Tidak mengherankan apabila mengacu pada argumentasi yang dikemukakan tersebut, kewenangan uji peraturan perundang-undangan di bawah undang-undang terhadap undang-undang yang ada di tangan Mahkamah Agung memiliki kelemahan baik secara formal maupun meteriil. Kelemahan secara formal terjadi apabila hak uji dilakukan melalui mekanisme kasasi akan memakan waktu yang lama, sedangkan secara materiil tidak terjaminnya kepastian hak uji peraturan perundang-undangan oleh MA apabila hak uji hanya berhenti di tingkatan peradilan pertama dan banding tanpa ada permohonan kasasi yang dilakukan terhadap MA. Kelemahan meteriil lainnya terjadi apabila permohonan 
diajukan langsung ke MA akan mencederai ketentuan Pasal 24 Ayat (2) UUD 1945.

\section{SIMPULAN}

Adanya pembagian kewenangan uji peraturan perundang-undangan antara Mahkamah Konstitusi dan Mahkamah Agung mengisyaratkan bahwa Indonesia tidak konsisten dengan konsep kekuasaan kehakiman yang sentralistik seperti tertuang dalam pasal ketentuan pasal 24A Ayat (1) dan Pasal 24C Ayat (1) UUD 1945. Apabila kewenangan untuk menguji peraturan daerah diberikan kepada Mahkamah Agung, berarti peraturan daerah mutlak hanya sebagai salah satu bentuk peraturan perundang-undangan yang berada di bawah undang-undang dan mengabaikan peraturan daerah itu sebagai "locale wet in materiele zin". Pembagian kewenangan uji peraturan perundang-undangan antata Mahkamah Konstitusi dengan Mahkamah Agung dapat menimbulkan perbedaan atau putusan yang saling bertentangan antara Mahkamah Konstitusi dengan Mahkamah Agung.

Berdasarkan uraian panjang di atas, adanya dualisme kewenangan judical review menimbulkan banyak problematika dalam pelaksanaannya. Oleh karena itu diperlukan adanya revitalisasi kewenangan Mahkamah Konstitusi yaitu tidak hanya terbatas melakukan uji undang-undang terhadap Undang-Undang

\section{DAFTAR RUJUKAN}

Ali, Achmad. 2009. Menguak Teori Hukum (legal theory) dan Teori Peradilan (judicialprudence) termasuk interpretasi Undang-undang (legisprudence). Jakarta: Kencana Prenada Media Group

Al Atok, A. Rosid. 2012. Saling Mengimbangi dan Saling Kontrol Antara Dewan Perwakilan Rakyat, Dewan Perwakilan Daerah, dan Presiden dalam Pembentukan Undang-Undang. Desertasi (Malang: Pasca Sarjana Fakultas Hukum Universitas Brawijaya).

Amsari, Feri. Masa depan MK: kesesuaian teori dan implementasi. (dimuat dalam jurnal konstitusi Mahkamah Konstitusi RI; vol.5 no. 1 juni 2008).

Asshiddiqie, Jimly. 2006. Perihal Undang-
Dasar 1945, tetapi harus diperluas dengan kewenangan uji seluruh perturan perundangundangan, sehingga Mahkamah Konstitusi benarbenar menjadi sebagai pengawal konstitusi (the guardian of the constitution).

Konsekwensi revitalisasi kewenangan Mahkamah Konstitusi diperlukan beberapa halhal pendukung, sehingga revitalisasi tersebut dapat dilaksanakan, diantaranya adalah: (1) Dasar hukum secara formal. Hal ini dapat dilakukan dengan penafsiran kata "undang-undang" dalam ketentuan Pasal 24C Undang-Undang dasar sebagai (wet in materiele zin) yaitu undangundang dipandang dalam arti meteriil sehingga seluruh peraturan perundang-undangan, termasuk peraturan daerah secara materiil dapat disebut sebagai undang-undang. Sehingga berdasarkan penafsiran ini, revitalisasi kewenangan Mahkamah Konstitusi cukup dibuatkan undang-undang khusus yang mengatur kewenangan Mahkamah Konstitusi melakukan uji seluruh peraturan perundangundangan. Namun untuk lebih sempurna, dalam agenda amandemen gagasan revitalisasi tersebut harus menjadi salah satu agenda. (2) Pemambahan jumlah hakim Mahkamah Konstitusi. Adanya penambahan kewenangan Mahkamah Konstitusi jelas akan menambah beban kerja hakim MK, sehingga perlu penambahan paling tidak menjadi 15 hakim MK sebagaimana hakim Mahkamah Konstitusi Italia. (3) Persiapan-persiapan teknis lainnya, seperti dukungan fasilitas yang memadai.

undang. Jakarta: Sekretariat Jenderal dan Kepaniteraan Mahkamah Konstitusi.

2004. Konstitusi dan Konstitusionalisme. Jakarta: Sekretariat Jenderal dan Kepaniteraan Mahkamah Konstitusi.

dan Safa'at, M. Ali. 2006. Teori Hans Kelsen Tentang Hukum. Jakarta: Sekretariat Jenderal dan Kepaniteraan Mahkamah Konstitusi. dan Syahrizal, 2012. Ahmad. Peradilan konstitusi di 10 negara. Jakarta: Sinar Grafika.

Harahap, Yahya. 2008. Kekuasaan Mahkamah Agung Pemeriksaan Kasasi dan Peninjauan Kembali Perkara Perdata. Jakarta: Sinar Grafika 
Mochtar, M. Akil, Peran Mahkamah Konstitusi Alam Negara Hukum Yang Demokratis. Makalah, disampaikan pada pendidikan sespati Polri dan Pasis Sespim Polri. Lembang, 6 juli 2009.
Thalib, Abdul Rasyid, 2006. Wewenang Mahkamah Konstitusi dan Implikasinya dalam sistem ketatanegaraan Republik Indonesia. Bandung: Citra Aditya Bakti. 